\title{
Occupational radiation risk caused by NORM in coal mining industry
}

\author{
K. Skubacz, B. Michalik and M. Wysocka \\ Laboratory of Radiometry, Central Mining Institute, 40-166 Katowice, Plac Gwarków 1, Poland \\ e-mail:m.wysocka@gig.eu
}

\begin{abstract}
The radiation risk due to the exposure to natural radionuclides, especially to short-lived radon progeny, is a component of the radiation hazard, common in the natural environment and working environment. In Polish mining industry the radiation hazard, caused by natural radionuclides is the natural hazard. Radon in air and radium present in underground brines are sources of radiation hazards. Sediments precipitated out from such waters with enhanced radium content may cause the increase of external gamma radiation dose rate as well as internal contamination due to accidental ingestion or inhalation.

Investigation of that specific problem has been started in hard coal underground mines in Poland in early 1970's. At the end of 1980's first regulation was issued. Dose limits and requirements of the radiation monitoring have been established, internal regulations for monitoring and mitigation measures were developed on the basis of the Polish standard. The monitoring and prevention against natural radiation is obligatory in all Polish underground mines since 1989. This duty is strictly supervised by local offices of State Mining Authority in co-operation with other governmental agencies.
\end{abstract}

\section{NATURAL SOURCES OF THE IONISING RADIATION IN UNDERGROUND MINES}

The radiation hazard is one of the natural hazards in underground mines like methane hazard, tremor hazard etc. The investigations of the natural radioactivity in underground mines in Poland have been started in early 1970's [Tomza \& Lebecka, 1981]. Firstly, efforts were focused on solving the problem of occurrence of radium-bearing waters and sediments with enhanced radioactivity in underground galleries. Next the importance of the exposure to radon progeny have been noticed. That main sources of natural radiation in Polish coal mines are short-lived radon progeny, radium isotopes in underground waters, deposits with enhanced radioactivity, precipitated out of radium-bearing mine waters [Lebecka et al., 1985].

The phenomenon of the radioactivity of saline waters from coal mines in Poland was discovered in the 1960's. Investigations showed, that radium concentration in water is correlated with the salinity [Tomza \& Lebecka, 1981]. In some cases, the total dissolved solids concentration exceeds $200 \mathrm{~kg} / \mathrm{m}^{3}$, whilst the radium concentration may reach $400 \mathrm{kBq} / \mathrm{m}^{3}$. The analysis of the radium isotopes in inflows showed, that the input of ${ }^{226} \mathrm{Ra}$ was of about $725 \mathrm{MBq}$ per day, while the corresponding value for ${ }^{228} \mathrm{Ra}$ was roughly $700 \mathrm{MBq}$ per day [Wysocka et al., 1996]. Only $40 \%$ of radium remained in the underground galleries and gauntons, whilst $60 \%$ were transported in pumped waters to the settling ponds on the surface and later to rivers [Lebecka et al., 1994]. It is an important source of contamination of the natural environment.

Two types of brine were distinguished. in coal mines in type A waters ions of barium and radium are present, while in type B waters only radium ions and sulphate occur, but no barium [Lebecka et al., 1986]. From type A waters radium is very easily precipitated out with barium carrier as sulphates after mixing with waters rich in sulphate ions. This is the source of sediments with enhanced radium content leading to the radioactive contamination and enhancement of gamma-dose rates. The highest levels of contamination are connected with release of A type waters and precipitation of insoluble deposits with enhanced radium content. 
In B type waters precipitation of radium scales doesn't occur. Radium from B-type waters is slowly adsorbed on suspended matter, therefore the level of contamination of underground work places and environment is much smaller in comparison with A type waters.

The main source of the radiation hazard to the mine crew is the exposure to short-lived radon progeny, present in the ventilation air [Skowronek et al., 1997]. In underground galleries radon and radon progeny concentrations occur in places with limited ventilation, confined in the rock body with many cracks and fissures. In coal mines in Upper Silesia region the radon concentration up to $15000 \mathrm{~Bq} / \mathrm{m}^{3}$ was measured. In monitoring of radon progeny in mines potential alpha energy concentration (PAEC) is measured expressed in joules per meter cubed and this term can be explained as the total energy, released during decay of radon progeny with alpha particles until their decay. The highest value of PAEC, measured in Polish coal mines, was $63 \mu \mathrm{J} / \mathrm{m}^{3}$. This measurement was performed close to old uranium workings. In coal mines of Upper Silesian Coal Basin (USCB) the highest PAEC values don't exceed $15 \mu \mathrm{J} / \mathrm{m}^{3}$ [Skowronek, 1999]. During several years of extended investigations the most important sources of radiation hazard in underground mines have been recognised. Methods of measurement have been developed, then suitable instrumentation for underground application was designed and system of radiological protection was implemented in all underground mines in Poland.

\section{LEGAL BASIS OF RADIOLOGICAL PROTECTION IN POLISH MINES, SYSTEM OF RADIOLOGICAL PROTECTION}

The system of radiation hazard monitoring and control has been developed in the Central Mining Institute, in co-operation with State Mining Authority and National Atomic Energy Agency. This system has been implemented in all mines in Poland in the end of 80's and obligatory carried out since 1989. The first legal basis of the monitoring was Polish standard "Radiation protection in underground mines. Limits of miners exposure to natural radionuclides and methods of monitoring". Monitoring in working environment is the most important issue of the established system. It should be followed by individual dosimetry in particular cases.

The most important regulatory act - The Geological and Mining Law - was issued in 1994, and amended in 2004 [Mining Law, 2005]. According to this law, criteria of the hazard assessment, also natural ones, must be establish by the President of State Mining Authority in co-operation with Ministry of Economy and must be co-ordinated with President of Polish Atomic Energy Agency. The safety requirements for underground workings were issued by Ministry of Internal Affairs and Administration [Decree, 2004]. The requirements concerning the assessment of radiation hazard were completed with requirements for protection against artificial and natural radionuclides, prevention measures and monitoring in the Decree of the Ministry of Economy [Decree, 2006], issued in agreement with the President of Polish Atomic Energy Agency. The system of radiological protection is a part of the overall system of natural and technical hazards monitoring, implemented in Polish mining industry.

Main guidelines of the system:

- it has a preventive type;

- the monitoring should be carried out by existing mine services, preferably together with monitoring of other types of hazards.

Monitored risk parameters are: potential alpha energy concentration of short living radon decay products, concentrations of Ra-226, Ra-228 and Pb-210 in mine waters, concentrations of Ra-226, Ra-228 and decay products in sediments, kerma rate in air (external gamma radiation) assessment of individual and committed doses.

\section{METHODS OF MONITORING AND MEASURING DEVICES}

\subsection{Radon progeny measurements}

The equilibrium factor $\mathrm{F}$ between radon and progeny in mine atmosphere is very unstable in location and time and varies from 0.05 to 0.95 [Skowronek, 1997]. Therefore the potential alpha energy concentration 


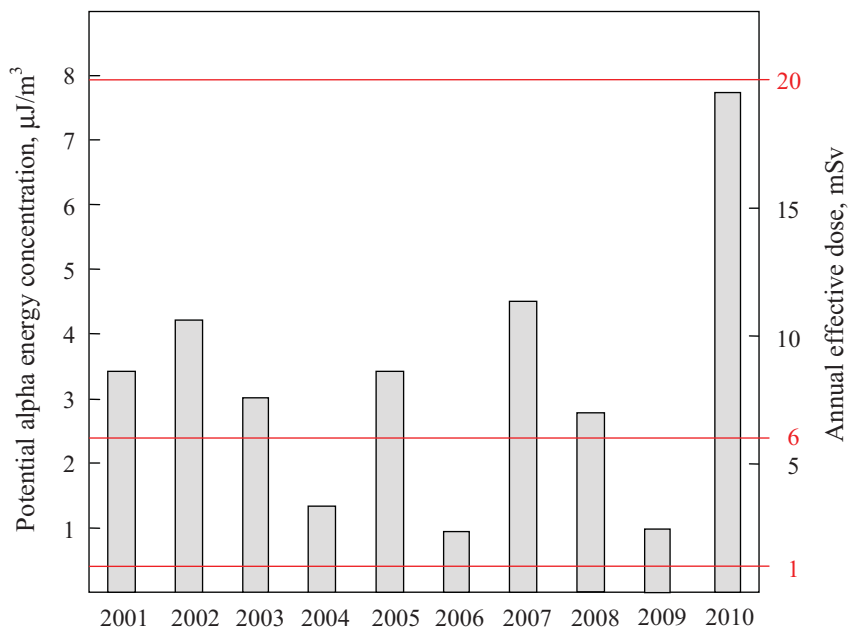

Figure 1. Maximum values of potential alpha energy concentration of radon progeny and calculated annual effective doses for last decade.

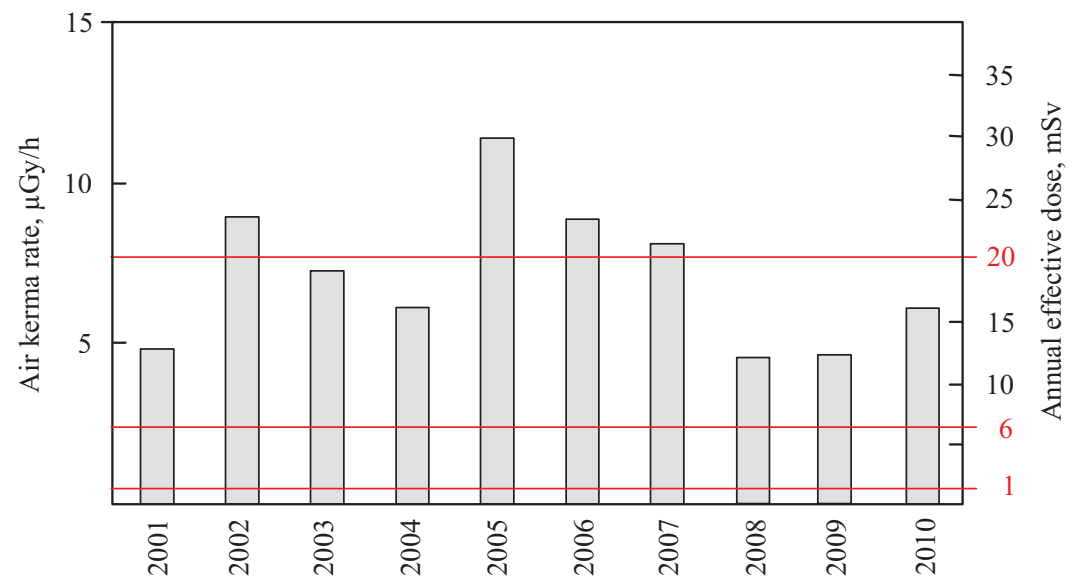

Figure 2. Maximum values of kerma rate and effective dose, caused by external gamma radiation.

of radon progeny is measured directly, to avoid errors due to the approximation of the exposure from radon data [Page, 1988]. For this purposes a typical, gravimetric dust sampler (Barbara 3A or personal dust sampler) is used. A special sampling probe (ALFA-31 or ALFA-2000) was designed [Lebecka et al., 1988, Skubacz, Bywalec, 2003]. Aerosols are collected on the membrane filter. Thermoluminescent detectors (TLD), mounted in a special holder above the filter, measure the alpha radiation, emitted by radon progeny. The device enables to perform measurements of dust content and radon progeny simultaneously, at little cost and effort.

\subsection{Gamma dose-rate measurements}

The special dosimeter for gamma dose rate measurements is designed. This device, (GAMMA-31) consists of a water- and dust-proof cassette, in which three thermoluminescent detectors $\mathrm{LiF}: \mathrm{Mg}, \mathrm{Cu}, \mathrm{P}$ (MCP-N type) are placed [Skubacz, 1986]. The GAMMA-31 dosimeter can be used not only as a personal dosimeter but also as the workplace monitor. 


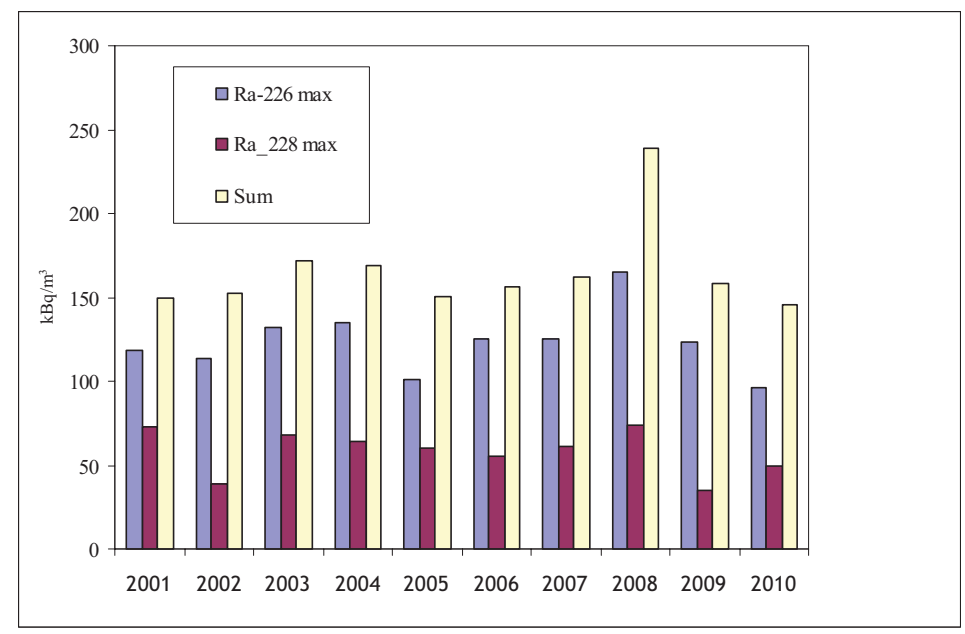

Figure 3. Maximum values of radium concentration in mine waters.

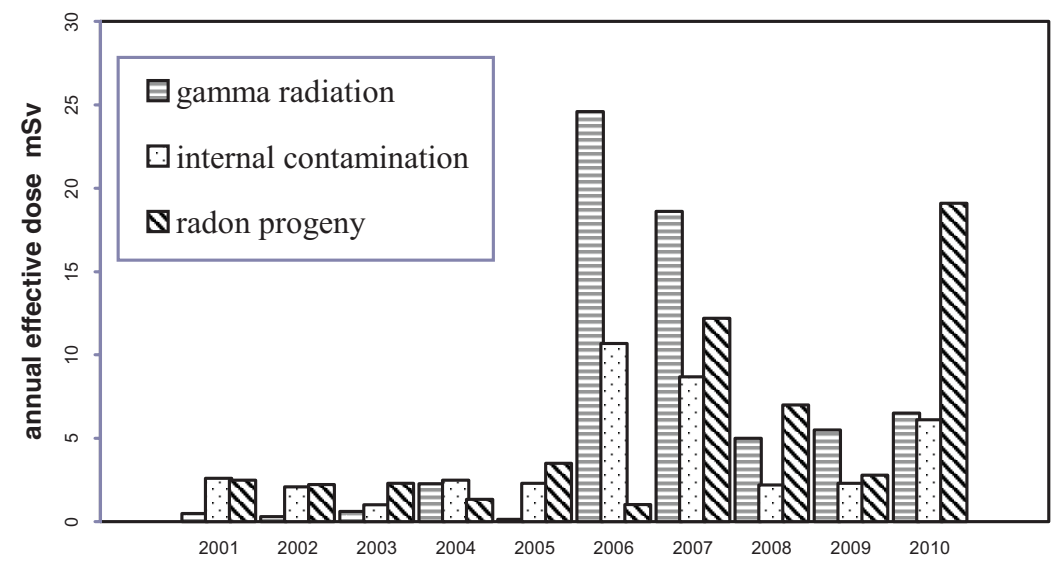

Figure 4. Values of maximum effective dose from different sources within last decade.

\subsection{Measurements of radium concentration in mine waters}

Radioactivity of waters from coal mines is mostly from radium isotopes $-{ }^{226} \mathrm{Ra}$ from the uranium series and ${ }^{228} \mathrm{Ra}$ from the thorium one. A method of chemical separation of radium, developed by Goldin [Goldin, 1961], has been modified for liquid scintillation counting [Chalupnik \& Lebecka, 1993]. In this method radium is co-precipitated with barium in form of sulphates and this precipitate is mixed with liquid gelling scintillator. The prepared samples are measured by a low background liquid scintillation spectrometer.

\subsection{Measurements of natural radionuclides in sediments}

Solid samples (deposits from settlement ponds, river beds, soil, solid waste, etc.) contain radio-isotopes from the uranium and thorium decay series, ${ }^{40} \mathrm{~K}$ and sometimes ${ }^{137} \mathrm{Cs}$, as the result of Chernobyl accident. For activity concentration measurement a gamma spectrometry system is used. It comprises of an HPGe detector (45\%, PGT), multichannel analyser (CANBERRA) with the GENIE-PC software 
for spectrum analysis (CANBERRA). It enables measurements of ${ }^{226} \mathrm{Ra}$ concentration (LLD as low as $1 \mathrm{~Bq} / \mathrm{kg}$ ), ${ }^{228} \mathrm{Ra}$ and ${ }^{224} \mathrm{Ra},{ }^{40} \mathrm{~K}$ and other natural and artificial isotopes emitting gamma radiation on the similar levels [Michalik, 1995]. Within the frame of obligatory monitoring system mine sediments are sampled in underground galleries or on the surface.

\section{ASSESSMENT OF THE EXPOSURE, CAUSED BY NATURAL RADIONUCLIDES IN UNDERGROUND MINES}

Results of monitoring of different parameters of radiation hazard are used for the assessment of effective dose for particular miners as well as a collective effective dose for all underground miners in Poland. Results of the consideration of annual effective dose are needed for the classification of galleries and workplaces, to ensure the proper span and frequency of monitoring and undertaking of preventive measures, if necessary. The most important source of radiation hazard in coal mines are radon progeny. Sometimes other sources i.e. gamma radiation, contamination by radium-bearing waters or sediments with enhanced radioactivity, may increase significantly the exposure of miners. Pictures 1,2,3 show values of particular risk parameters measured in Polish coal mines for last 10 years. Figure 4 present values of maximum effective dose from different sources within last decade.

To assess radiation doses in underground mines the web application was designed. The main tasks of the system are: planning the necessary measurements, reporting of research results, calculation of effective doses, radiological risk assessment (automatic and simulation), evaluation of category of employees and working places, planning of next measurements, data sharing of all authorized users of the system and implementation of statistical tasks. The resources of the system, which consists of information necessary to evaluate the dose, are actively changed by a laboratory performing measurements and customers, where these measurements are performed.

\section{CONCLUSIONS}

The main sources of natural radiation in Polish coal mines are short-lived radon progeny, radium isotopes in underground waters, deposits with enhanced radioactivity, precipitated out of radium-bearing mine waters.

The system of the monitoring of radiation hazard in Polish mining industry is a unique, complete system, first implemented in non-uranium industry. This system enables not only the assessment of miners exposure but due to the fact, that results can be obtained quickly, provides data necessary for preventive measures.

\section{References}

[1] Chalupnik S., Lebecka J., 1993, Determination of ${ }^{226} \mathrm{Ra},{ }^{228} \mathrm{Ra}$ and ${ }^{224} \mathrm{Ra}$ in water and aqueous solutions by liquid scintillation counting, Liquid Scintillation Conference, RADIOCARBON, pp. 397-403.

[2] Decree of Ministry of Economy, 2004, Dz.U.Nr 2002, poz. 94, 841.

[3] Decree of Ministry of Economy 2006, Dz.U. Nr 124, poz. 863.

[4] Goldin A.S., Analytical Chemistry, vol. 33, p. 406, 1961.

[5] Lebecka J., Skubacz K., Chałupnik S., Tomza I., Pluta I., Skowronek J., 1986, Influence of mining activity on distribution of radium in the natural environment, 4th Working Meeting Isotopes in Nature, Leipzig, Proceedings, Part II, s. 423-428

[6] Lebecka J., Skowronek J., Tomza I., Michalik B., Chałupnik S., Skubacz K., A thermoluminescent monitor of low radon - daughter concentrations in air. 1988 Journal of Applied Radiation and Isotopes, vol. 39, No. 9/88, p. 987 - 992 
[7] Lebecka J., Chałupnik S., Michalik B., Wysocka M., Skubacz K., Mielnikow A., Radioactivity of Mine Waters in Upper Silesian coal basin and its Influence on natural environment. 1994 5th International Mine Water Congress, Nottingham (U.K.)

[8] Michalik B.,. Chałupnik S, Skowronek J., Lebecka J., Guidlines for treatment of solid wastes with enhanced natural radioactivity in Polish coal industry 1995 Symposium on Radiation Protection Neighboring Counties in Central Europe, Slovenia, Portoro 1995, s. 145 - 149

[9] Michalik B. i in. (2005): Metoda oceny skutecznych dawek obciążających związanych z wniknięciem izotopów promieniotwórczych według różnych scenariuszy zagrożenia radiacyjnego, Główny Instytut Górnictwa, Katowice.

[10] Page D., The distribution of Radon and its decay products in some UK coal mines, Fifth International on the Natural Radiation Environment, Salzburg 1988.

[11] Polish Atomic Law - Ustawa Prawo atomowe (DZ. U. z 2007 r. Nr 42, poz. 276)

[12] Skowronek J., Skubacz K., Michalik B., Kajdasz R., Strześniewicz Z., Moritoring and control of the radon hazard in Polish coal mines. 1997 Int. Symp. "Radon and Thoron in Human Environment", Oct. 24-25, Fukuoka, Japan

[13] Skowronek J. et al. - Radiation hazard in Polish coal Mines - Annual Report 1999, Central Mining Institute, Katowice 1999 (in Polish).

[14] Skubacz K., Lebecka J., Tomza I., 1986, Dawkomierz GAMMA-31 - przyrząd do pomiaru mocy dawki promieniowania gamma w wyrobiskach podziemnych, Post. Fiz. Med., str.249 - 254 (in Polish)

[15] Skubacz K., Bywalec T., 2003. Monitoring of the radiation hazard caused by short-lived radon daughters in mines. Radiation Protection Dosimetry. Vol. 103, No 3, p.241-246.

[16] Tomza I., Lebecka J., 1981, Radium-bearing waters in coal mines: occurrence, methods of measurements and radiation hazard - Int. Conf. On Radiation Hazards in Mining, Golden, Co

[17] Wysocka M., Skubacz K., Michalik B., Mielnikow A., Chałupnik S. (2010): Zagrożenia radiacyjne w podziemnych zakładach górniczych, Bezpieczeństwo Pracy i Ochrona Środowiska w Górnictwie, Miesięcznik Wyższego Urzędu Górniczego 5(153)/2007. 